Egyptian Journal of Aquatic Biology \& Fisheries

Zoology Department, Faculty of Science,

Ain Shams University, Cairo, Egypt.

ISSN $1110-6131$

Vol. 22(5): 431- 445 (2018)

www.ejabf.journals.ekb.eg

\title{
Influence of several dietary protein and lipid levels on nutritional parameters and liver functions of Solea aegyptiaca juveniles
}

\author{
Abdel-Moniem M. Yones ${ }^{*}$, Hani M. Nazmi, Atallah A. Metwalli \\ Fish Nutrition Lab., Aquaculture Division, National Institute of Oceanography and \\ Fisheries (NIOF), Cairo, Egypt \\ *Corresponding author: yones_55200010@yahoo.com)
}

\section{ARTICLE INFO \\ Article History: \\ Received: Nov.18, 2018 \\ Accepted: Dec. 22, 2018 \\ Online: Dec. 30, 2018}

\section{Keywords:}

Solea aegyptiaca

Protein level

Lipid level

Liver enzyme activities

Growth performance

Digestibility coefficient

\begin{abstract}
A feeding trial was designed to assess the effects of dietary protein and lipid content on growth, feed utilization efficiency, and muscle proximate composition of Solea aegyptiaca juveniles. Eight diets were formulated (4 protein levels; 40, 45, 50\& 55\% at 2 lipid levels; $8,12 \%$ ). The results showed that growth performance in terms of weight gain, specific growth rate, condition factor, feed conversion ratio, protein efficiency ratio and net protein utilization were much higher for fish group fed on a diet contained $45 \%$ protein at $12 \%$ lipid than the rest of experimental groups. The feed intake of experimental fish tended to reduce with rising dietary lipid levels. No significant differences in Solea aegyptiaca for digestibility coefficient and body chemical composition were observed. The body content of lipid and liver enzymes (alanine aminotransferase and aspartate aminotransferase) activities were positively correlated with dietary lipid levels. The present results pointed to the diet containing $45 \%$ protein and $12 \%$ lipid with 22.5 $\mathrm{MJ} / \mathrm{kg}^{-1}$ had a protein-sparing effect and was optimal for Solea aegyptiaca juveniles.
\end{abstract}

\section{INTRODUCTION}

Protein is considered the highest cost component in fish meals and plays a critical role in fish growth performance. The researchers pointed out more benefits of protein (as the main content in fish diets) like using it in metabolic energy, utilizing the synthesis of muscle tissue, etc. (Williams et al., 2003; Ozorio et al., 2006). Protein sparing by lipid has been recorded only in the salmonids fish (Azevedo et al., 2004), and by non-protein energy sources in a large scale of species (Thoman et al., 1999; Azevedo et al., 2004; Kim and Lee, 2005).

The precise data on the protein requirement for fish is very essential for any new aquaculture activity in light of the high cost of protein ingredients $(\mathrm{Ng}$ et al., 2008). The usage of dietary protein is identified with both protein levels and accessibility of non-protein energy sources (Ai et al., 2004). Ideally, dietary lipids or carbohydrates ought to be expanded in fish feeds to save dietary protein from being utilized for energy (Deng et al., 2011). Lessening the dietary protein content by expanding fat as well as edible carbohydrate content, with no negative impact on the growth performance is known as "the protein-sparing effect"(Yamamoto et al., 2005). 
A recent study on the manufacture of aqua feed show that elevated levels of lipid concentrations in the diet and improving fish performance considers an important target. Dietary lipids play a conspicuous role in fish nutrition as a primary energy source and to provide essential fatty acids to maintain biological structures and normal functions of cell membranes (Sargent et al., 1999). Increasing dietary lipid levels improves diet efficiency by minimizing protein degradation (Peres and Olı'va-Teles, 1999).

The large attention to fish oil was reported done in many human health studies due to its high content of unsaturated fatty acids (HUFA). Also, fish oil is the main source of lipid which used in the formulation of the diet for many marine fish species (Nasopoulou and Zabetakis, 2012). On the other hand, the continuous increasing of world vegetable oil production, elevated the interest to use vegetable oils for fish feed to partial replacement and reducing the dependency on fish oil (Montero et al., 2008; Xu et al., 2015).

The successful extending of fish culture required to consider the cost and refined fish species for new aquaculture. Individuals from the genus Solea sp., are reported among the most vital and significant commercial flatfishes in Egypt (Gabr et al., 2003). In Egypt, the first hatching of common sole (Solea solea) was observed in 1986 (Zaki and Hamza, 1986, 1988; Assem et al., 2012). Senegalese sole is a common flatfish in the Mediterranean and considered to be one of an attractive species for mariculture expansion in this area (Imsland et al. 2003; Canãvate et al., 2006), which has the similar growth of that other aquaculture fish species such as Gilthead sea bream or Sea bass (Dinis et al., 1999; Imsland et al., 2003). In Egyptian Qaroun Lake, the total Egyptian sole catch was represented from 35 to $50 \%$ of total lake catch production, according to different seasons (Kariman, 2009).

In spite of the successful progress in hatching, rearing larvae and weaning stage for Sole fish was investigated, the shortage information about this species still standing (Dinis et al., 2000; Conceic, a o et al., 2007). Thus, extensive efforts was achieved in studying the nutrient requirements of Sole, but some essential aspects of nutrition and physiology of this kind of fish are still missing. The fundamental assessment shows that Sole juveniles require $530 \mathrm{~g} \mathrm{~kg}^{-1}$ dietary protein for the highest growth rate (Rema et al., 2008) and for Solea aegyptiaca $550 \mathrm{~g} \mathrm{~kg}^{-1}$ (Yones and Abdel-Hakim, 2011). Otherwise, Guerreiro et al. (2012) reasoned that dietary protein could be diminished from $550 \mathrm{~g} \mathrm{~kg}^{-1}$ to $450 \mathrm{~g} \mathrm{~kg}^{-1}$, without influencing on fish performance by rising dietary lipid or carbohydrate level. Protein represents as a major factor of diet cost and optimizing protein utilization is essential for the sustainability of fish production. Dias et al. (2004) reported that Senegalese sole growth was identical with $110 \mathrm{~g}$ or $210 \mathrm{~g} \mathrm{~kg}^{-1}$ of lipids. Furthermore, Borges et al. (2009) concluded that Senegalese sole juveniles have low lipid tolerance and recommended that maximum dietary lipid inclusion should be limited to $80 \mathrm{~g} \mathrm{~kg}^{-1}$ for the best nutrient utilization and optimal growth. Guerreiro et al. (2012) studied the effect of dietary levels of protein $\left(450 \mathrm{~g} \mathrm{~kg}^{-1}\right.$ and $\left.550 \mathrm{~g} \mathrm{~kg}^{-1}\right)$ and lipid $\left(80 \mathrm{~g} \mathrm{~kg}^{-1}\right.$ and $160 \mathrm{~g} \mathrm{~kg}^{-1}$ ) on performance of Sole juveniles and revealed the best feed utilization with the diet including $550 \mathrm{~g} \mathrm{~kg}^{-1}$ protein and $80 \mathrm{~g} \mathrm{~kg}^{-1}$ lipid. However, the growth was identical with the diets of $450 \mathrm{~g} \mathrm{~kg}^{-1}$ protein and $160 \mathrm{~g} \mathrm{~kg}^{-1}$ lipid, this suggesting that the protein spared by dietary lipids. Hence, it is vital to decide the correct dietary protein, energy levels and/or their ratio for boosting growth rate, feed utilization and lowering the environmental impact on fish farms. In flatfishes, a protein sparing by dietary lipids was beforehand recorded in Atlantic halibut (Helland and GrisdaleHelland, 1998) and Turbot fishes (Cho et al., 2005). In other studies in flatfishes were 
not able to demonstrate a protein sparing by dietary lipid (Berge and Storebakken, 1991), whilst the drooping in growth was observed at high levels of dietary lipids (Lee et al., 2000; Regost et al., 2001). These conflicting consequences might be linked to the protein/lipid ratio of the experimental diets. For example, Andersen and Alsted (1993) observed that protein contents in Turbot have a huge impact in dietary lipid.

The present study was conducted to evaluate the effects of dietary protein and lipid levels as practical feeds on growth performance, feed utilization, digestibility coefficient and body composition of Solea aegyptiaca fish.

\section{MATERIALS AND METHODS}

\section{Fish and Experimental Design}

Sole, Solea aegyptiaca juveniles were obtained from Qaroun Lake to the experimental tanks of the Fayoum research station, National institute of oceanography and fishers, Egypt. The rearing tanks were supplied with water from the Qaroun Lake by two water pumps, each pump was drowning the water to the water storage tanks after it passes on upstream sandy filter units, then water forced through polyvinyl chloride (PVC) tubes into the fish rearing tanks with a flow rate of $3 \mathrm{~L} / \mathrm{min}$, approximately. The continual aeration in each rearing tank was maintained throughout the experimental rearing period. Prior to starting the experiment, the juveniles of Sole fish were stocked and reared in circular fiberglass tanks for 2 weeks in order to acclimatize it in the experimental conditions. Through this period, the Sole fishes were fed twice daily on a control diet. At the beginning of the experiment, the fish were fasted for $24 \mathrm{~h}$ before weighing. The fishes of similar sizes (initial weight of $10.62 \pm 0.28 \mathrm{~g}$ ) were distributed into twenty-four fiberglass tanks (water volume for each tank was $1 \mathrm{M}^{3}$ ) with 30 juveniles per tank. Each treatment of this experiment was randomly specified to triplicate tanks. The fishes were hand-fed to apparent satiation twice (10:00 a.m. and 4:00 p.m.) daily and weighing every two weeks to adjust the amount of feed consumption. The trial was conducted for a period of 120 days (from May to August 2016). Physicochemical characteristics of water for every tank were analyzed weekly according to (APHA, 1992).

\section{Experimental Diets}

All experimental diets were consisted of various commercial ingredients by using fish meal as a protein source, fish oil, sunflower oil as a lipid source and wheat bran as a carbohydrate source. The ingredients were mixed and grounded into a fine powder image through a $175-\mu$ mmesh. Hence, the diets were pelleted by California pelleting machine with $2 \mathrm{~mm}$ diameter and stored in a refrigerator at $5^{\circ} \mathrm{c}$ until used. Eight diets were formulated (4 protein levels; 40, 45, 50 and 55\% at 2 lipid levels; 8, $12 \%$ ) with different ratios of gross energy ranging from 20.87 to $23.51 \mathrm{MJ} \mathrm{kg}^{-1}$ diet (Table, 1). Chromic oxide $\left(\mathrm{Cr}_{2} \mathrm{O}_{3}\right)$ as an inert marker was added in diets to assess the apparent nutrient digestibility. 
Table 1: Formulation and proximate composition of experimental diets (\% D.M basis).

\begin{tabular}{|c|c|c|c|c|c|c|c|c|}
\hline \multirow{2}{*}{ Ingredients } & \multicolumn{8}{|c|}{ Diets (protein/lipid \%) } \\
\hline & $(40 / 8 \%)$ & $(45 / 8 \%)$ & $(50 / 8 \%)$ & $(55 / 8 \%)$ & $(40 / 12 \%)$ & $(45 / 12 \%)$ & $(50 / 12 \%)$ & $(55 / 12 \%)$ \\
\hline Fish meal & 20.0 & 30.0 & 40.0 & 55.0 & 20.0 & 30.0 & 40.0 & 60.0 \\
\hline Poultry-by product meal & 20.0 & 20.0 & 25.0 & 20.0 & 24.0 & 20.0 & 25.0 & 18.0 \\
\hline Soybean meal & 24.0 & 22.0 & 15.0 & 10.0 & 20.0 & 23.0 & 15.0 & 5.0 \\
\hline Wheat bran & 26.0 & 18.0 & 10.0 & 5.0 & 22.0 & 13.0 & 6.0 & 3.0 \\
\hline Fish oil & 4.0 & 4.0 & 4.0 & 4.0 & 6.0 & 6.0 & 6.0 & 6.0 \\
\hline Sunflower oil & 4.0 & 4.0 & 4.0 & 4.0 & 6.0 & 6.0 & 6.0 & 6.0 \\
\hline Vitamin Min. Mix $^{1}$ & 2.0 & 2.0 & 2.0 & 2.0 & 2.0 & 2.0 & 2.0 & 2.0 \\
\hline \multicolumn{9}{|c|}{ Proximate analysis (\%D.M.) } \\
\hline Dry matter & 92.8 & 92.6 & 92.5 & 92.8 & 92.6 & 92.5 & 92,7 & 92.6 \\
\hline Crude Protein & 40.36 & 45.28 & 50.6 & 55.2 & 40.12 & 45.06 & 50.04 & 55.0 \\
\hline Crude lipid & 14.85 & 16.25 & 17.07 & 18.16 & 19.64 & 20.11 & 21.46 & 22.63 \\
\hline N.F.E & 30.26 & 24.11 & 17.52 & 11.45 & 26.67 & 21.29 & 13.97 & 7.84 \\
\hline Crude fiber & 4.47 & 4.05 & 3.15 & 2.38 & 4.43 & 3.63 & 2.78 & 1.91 \\
\hline GE/ MJ kg-1 diet $^{2}$ & 20.87 & 21.52 & 21.96 & 22.42 & 22.08 & 22.5 & 22.94 & 23.51 \\
\hline ME/MJ kg ${ }^{-1}$ diet $^{3}$ & 17.36 & 17.89 & 18.22 & 18.75 & 18.51 & 18.8 & 19.16 & 19.61 \\
\hline
\end{tabular}

1-Vitamin mineral premix (mg or IU/kg of diet): thiamin, $24.5 \mathrm{mg}$; riboflavin, $36 \mathrm{mg}$; pyridoxine $\mathrm{HCl}$, 19.8mg; vitamin B12, 0.1mg; vitamin K3, $5.1 \mathrm{mg}$; inositol, 784mg; pantothenic acid, $58.8 \mathrm{mg}$; niacin acid, $198 \mathrm{mg}$; folic acid, $19.6 \mathrm{mg}$; biotin, $1.20 \mathrm{mg}$; retinol acetate, 16,000 IU; cholecalciferol, $2500 \mathrm{IU}$; alpha-tocopherol, $200 \mathrm{mg}$; choline chloride $(50 \%), 2500 \mathrm{mg}$; ascorbic acid (35\%),1000 mg; mold inhibitor, 1000mg and ethoxyquin, 500mg; $\mathrm{MgSO}_{4} \cdot 7 \mathrm{H}_{2} \mathrm{O}, 1200 \mathrm{mg} ; \mathrm{CuSO}_{4} \cdot 5 \mathrm{H}_{2} \mathrm{O}, 10 \mathrm{mg} ; \mathrm{ZnSO}_{4} \cdot \mathrm{H}_{2} \mathrm{O}$, $50 \mathrm{mg} ; \mathrm{FeSO}_{4} \cdot \mathrm{H}$

${ }_{2} \mathrm{O}, 80 \mathrm{mg} ; \mathrm{MnSO}_{4} \cdot \mathrm{H}_{2} \mathrm{O}, 45 \mathrm{mg} ; \mathrm{COCl}(1 \%), 50 \mathrm{mg} ; \mathrm{Na}_{2} \mathrm{SeO}_{3}(1 \%), 20 ; \mathrm{Ca}\left(\mathrm{IO}_{3}\right)_{2}(1 \%), 60 \mathrm{mg}$; Zeolite, $85 \mathrm{mg} ; \mathrm{Ca}\left(\mathrm{H}_{2} \mathrm{PO}_{3}\right)_{2} \cdot \mathrm{H}_{2} \mathrm{O}, 5000 \mathrm{mg}$.

2-Gross energy ( $\mathrm{MJ} \mathrm{Kg}^{-1}$ diet) was calculated by using the following calorific values: 23.9, 39.8 and $17.6 \mathrm{KJ} \mathrm{g}^{-1}$ diet for protein, ether extract and nitrogen free extract, respectively (Lozano, 2007). 3-The metabolizable energy $\left(\mathrm{MJ} \mathrm{Kg}^{-1}\right.$ diet) of the experimental diets were calculated as 18.9, 35.7 and 14.7 $\mathrm{KJ} \mathrm{g}^{-1}$ diet for protein, lipid and nitrogen free extract, respectively (Jobling, 1994).

\section{Growth Performance and Feed Utilization}

The parameters for growth and feed utilization were calculated as follows:

Weight gain, WG (gm/fish) = final weight - initial weight.

Average daily gain, ADG (gm/fish/day) = total weight gain $(\mathrm{gm}) /$ period (day).

Condition Factor $(\mathrm{K})=$ fish weight, grams $/(\text { fish length, } \mathrm{cm})^{3} \times 100$.

Specific growth rate, $\mathrm{SGR}=\mathrm{LnW}_{2}-\mathrm{LnW}_{1} / \mathrm{T} \times 100$.

Where: $\mathrm{Ln}=$ the natural $\log$.

$\mathrm{W}_{2}=$ final weight at certain period $(\mathrm{gm})$.

$\mathrm{W}_{1}=$ Initial weight in the same period $(\mathrm{gm})$.

$\mathrm{T}=$ period of experiment (day).

Survival rate, SR $(\%)=$ No. of surviving fishes/total No. of fishes at the beginning $\times 100$.

Feed conversion ratio $(\mathrm{FCR})=$ feed intake $(\mathrm{gm}) /$ weight gain $(\mathrm{gm})$.

Protein efficiency ratio $(\mathrm{PER})=$ Weight gain $(\mathrm{gm}) /$ Crude protein intake $(\mathrm{gm})$.

Net protein Utilization $($ NPU \%) $=100$ (Final body protein, gm - initial body protein, $\mathrm{gm} /$ protein intake, gm).

\section{Fish Samples and Chemical Analysis}

At the experimental start, nine fishes were randomly collected and divided into three pooled groups to serve as an initial fish sample and stored frozen at $-20{ }^{\circ} \mathrm{C}$ for doing the carcass composition analysis according to the procedures described by Standard Methods (AOAC, 2006). At the experimental end, all fishes fasted for $24 \mathrm{~h}$ before harvest and the same step for collected fish samples was made for each treatment (9fishes/replicate). Also, the proximate analysis of experimental diet composition was occurred according to the same procedures mentioned above. 


\section{Digestibility trail}

After the sample collection described above, the remaining fish were reared and fed with the similar diets after adding $0.5 \%$ Chromic oxide $\left(\mathrm{Cr}_{2} \mathrm{O}_{3}\right.$, as an inert marker) to define the apparent digestibility coefficients (ADCs) as an indicator for nutrient digestibility. The fish feces were collected after passing the time of fish feeding from 5-6 hours. Fishes from each treatment were anesthetized with MS-222 $(50 \mathrm{mg} / \mathrm{L})$ and manually stripped of feces by applying gentle pressure in the anal area according to the method described by Borges et al. (2013). The amounts of feces were collected and stored at $-20^{\circ} \mathrm{C}$ until a sufficient amount of dried feces had been covered for analysis. The fish feces and treated diets with Chromic oxide additive were determined using an inductively coupled plasma-atomic emission spectrophotometer (IRIS Advantage [HR], Thermo Jarrell Ash, Woburn, MA, USA) after Perchloric acid digestion, triplicate analysis have been made for each sample of each treatment. ADCs $\%$ of nutrient was calculated according to the following equation:

ADC of nutrients $(\%)=100-\left(100 \times\right.$ nutrient in feces $\% /$ nutrient in diet $\% \times \mathrm{Cr}_{2} \mathrm{O}_{3} \%$ in $\operatorname{diet} / \mathrm{Cr}_{2} \mathrm{O}_{3} \%$ in feces).

\section{Liver functions}

Hepatosomatic index (HSI) was defined for each liver by weighed it after excised from nine collected fishes per treatments, then frozen in liquid nitrogen and stored at $-80^{\circ} \mathrm{C}$ to define whole lipid, glycogen, alanine aminotransferase, ALT and aspartate aminotransferase, AST. The whole lipid of liver samples was defined according to the followed method of Folch et al. (1957), whereas liver glycogen was defined by a colorimetric enzymatic method using commercial kits (supplied by Nanjing Jiancheng Bio-Tech Co., Nanjing, China). The followed method for assaying protein-metabolism enzyme activities from Liver crude extract was obtained by homogenization of frozen tissue in ice-cold $0.7 \%$ saltwater and following by centrifugation stage ( $3200 \mathrm{rpm}$, for $20 \mathrm{~min}$ at $4^{\circ} \mathrm{C}$ ). Activities of liver enzymes ALT and AST were measured using specific analytical procedures and commercially available kits (supplied by Nanjing Jiancheng Bio-Tech Co., Najing, China). Lipase activity was defined by the method of Pan and Wang (1997). HSI was calculated as a percentage of the whole fish weight as follows:

Hepatosomatic index (HSI) $=100$ [liver weight $(\mathrm{g}) /$ fish body weight $(\mathrm{g})]$.

\section{Statistical Analysis}

The resulted data of different levels and their interactions were performed using statistical SPSS software version 18 (IBM Corp., New York, USA). The homogeneity test of variances was done for trialed data. Duncan post-hoc test with multiple ranges (Duncan, 1955) was obtained to compare differences among means at 5\% significance level (Differences were regarded as significant when $\mathrm{P}<0.05$ ).

\section{RESULTS}

The analysis of variance achieved to determine whether there were differences between treated groups, and a possible interaction between protein and lipids.

The resulted data in this nutritional trail were found that, a clear correlation between protein and lipid levels in feeding Solea aegyptiaca juveniles. The data in Table (1) showed that there is a clear variation in the diets constitutes from protein and lipid levels. Also, sunflower oil and fish oil were incorporated in all experimental diets as a percent of 1:1 in order to spare $50 \%$ of high price fish oil. 
From Table (2), the results reported that the water physicochemical characteristics such as temperature, salinity, $\mathrm{pH}$, dissolved oxygen and unionized ammonia are in the optimum rates for Sole farming according to Fonds (1976). The resulted data showed constant physicochemical results in all fish tanks.

Table 2: The mean of water physicochemical characteristics features during the trial interval.

\begin{tabular}{|c|c|c|c|c|c|c|c|c|}
\hline \multirow{2}{*}{ Parameters } & \multicolumn{8}{|c|}{ Diets (protein/lipid \%) } \\
\hline & $(40 / 8 \%)$ & $(45 / 8 \%)$ & $(50 / 8 \%)$ & $(55 / 8 \%)$ & $(40 / 12 \%)$ & $(45 / 12 \%)$ & $(50 / 12 \%)$ & $(55 / 12 \%)$ \\
\hline Temperature $\left({ }^{\circ} \mathrm{C}\right)$ & $28.2 \pm 0.2$ & $28.5 \pm 0.3$ & $28.3 \pm 0.2$ & $28.4 \pm 0.4$ & $28.4 \pm 0.3$ & $28.4 \pm 0.2$ & $28.2 \pm 0.2$ & $28.2 \pm 0.2$ \\
\hline Salinity (g/l) & $33.2 \pm 1.2$ & $33.1 \pm 1.2$ & $33.2 \pm 1.2$ & $33.1 \pm 1.2$ & $33.1 \pm 1.1$ & $33.1 \pm 1.2$ & $33.1 \pm 1.1$ & $33.1 \pm 1.2$ \\
\hline pH & $7.6 \pm 0.3$ & $7.8 \pm 0.2$ & $7.5 \pm 0.2$ & $7.8 \pm 0.2$ & $7.6 \pm 0.4$ & $7.5 \pm 0.3$ & $7.8 \pm 0.2$ & $7.6 \pm 0.2$ \\
\hline Dis. Oxy ${ }^{1}$ (mg/l) & $6.2 \pm 0.1$ & $6.1 \pm 0.2$ & $6.2 \pm 0.4$ & $6.1 \pm 0.2$ & $6.0 \pm 0.2$ & $6.2 \pm 0.1$ & $6.1 \pm 0.2$ & $6.2 \pm 0.2$ \\
\hline Uni. am. ${ }^{2}$ (mg/l) & $0.03 \pm 0.01$ & $0.03 \pm 0.01$ & $0.02 \pm 0.01$ & $0.03 \pm 0.01$ & $0.02 \pm 0.01$ & $0.03 \pm 0.01$ & $0.03 \pm 0.01$ & $0.04 \pm 0.01$ \\
\hline
\end{tabular}

1-Dissolved oxygen. 2-Unionized ammonia

The recorded averages of initial weights of Egyptian sole (Solea aegyptica) ranged between 10.4 to $11.0 \mathrm{~g} /$ fish with no significant differences among the treatments, which referred that the random distribution of the trial fish among dietary groups as in Table (3) and Figure (1). Interestingly, the data in Table (3) explained that the survival ratio of fishes in all dietary groups during the experiment was $98 \%$. This showed that the used diets increased the survival rates of Sole fish. On other hand, the deceased fish ratios were resulted of the external factors during the samples collection every two weeks to adjust the amounts of feed intake. The data in Table (3) showed that the dietary protein and lipid levels effect significantly $(\mathrm{P}<0.05)$ on growth performance, feed utilization, and there interactions between them. From Table 3 , the data indicated that the diet $(45 / 12 \%$, protein/lipid) had significant increasing in weight gain and specific growth rate $(\mathrm{P}<0.05)$ higher than other dietary groups. However, fish fed by the diet of (40/8, 45/8 and 40/12\%, protein/lipid) showed a decrease in growth performance and feed utilization.

Table 3: Effect of various diets on the growth performance of Egyptian sole (Solea aegyptica) fishes.

\begin{tabular}{|c|c|c|c|c|c|c|c|c|}
\hline \multirow{2}{*}{ Parameters } & \multicolumn{8}{|c|}{ Diets (protein/lipid \%) } \\
\hline & $(40 / 8 \%)$ & $(45 / 8 \%)$ & $(50 / 8 \%)$ & $(55 / 8 \%)$ & $(40 / 12 \%)$ & $(45 / 12 \%)$ & $(50 / 12 \%)$ & $(55 / 12 \%)$ \\
\hline $\begin{array}{l}\text { Initial weight } \\
\text { (g/fish) }\end{array}$ & $\begin{array}{l}10.5 \\
\pm 0.3\end{array}$ & $\begin{array}{l}10.4 \\
\pm 0.3\end{array}$ & $\begin{array}{l}11.0 \\
\pm 0.3\end{array}$ & $\begin{array}{l}10.6 \\
\pm 0.3\end{array}$ & $\begin{array}{l}10.2 \\
\pm 0.3\end{array}$ & $\begin{array}{l}11.0 \\
\pm 0.3\end{array}$ & $\begin{array}{l}10.5 \\
\pm 0.3\end{array}$ & $\begin{array}{l}10.8 \\
\pm 0.3\end{array}$ \\
\hline Final weight (g/fish) & $\begin{array}{l}35.4^{\mathrm{c}} \\
\pm 1.4\end{array}$ & $\begin{array}{l}36.2^{\mathrm{c}} \\
\pm 1.2\end{array}$ & $\begin{array}{l}38.4^{\mathrm{b}} \\
\pm 1.5\end{array}$ & $\begin{array}{l}38.4^{\mathrm{b}} \\
\pm 1.2\end{array}$ & $\begin{array}{l}36.5^{\mathrm{c}} \\
\pm 1.1\end{array}$ & $\begin{array}{l}42.8^{\mathrm{a}} \\
\pm 1.8\end{array}$ & $\begin{array}{l}38.6^{\mathrm{b}} \\
\pm 1.4\end{array}$ & $\begin{array}{l}39.1^{\mathrm{b}} \\
\pm 1.2\end{array}$ \\
\hline $\begin{array}{l}\text { Total weight gain } \\
\text { (g/fish) }\end{array}$ & $\begin{array}{l}24.9^{\mathrm{c}} \\
\pm 1.1\end{array}$ & $\begin{array}{l}25.8^{\mathrm{c}} \\
\pm 1.4\end{array}$ & $\begin{array}{l}27.4^{\mathrm{b}} \\
\pm 1.2\end{array}$ & $\begin{array}{l}27.8^{\mathrm{b}} \\
\pm 1.1\end{array}$ & $\begin{array}{l}26.3^{\mathrm{c}} \\
\pm 1.4\end{array}$ & $\begin{array}{l}31.8^{\mathrm{a}} \\
\pm 1.1\end{array}$ & $\begin{array}{l}28.1^{\mathrm{b}} \\
\pm 1.2\end{array}$ & $\begin{array}{l}28.3^{\mathrm{b}} \\
\pm 1.4\end{array}$ \\
\hline $\begin{array}{l}\text { Average weight gain } \\
\text { (g/fish/d) }\end{array}$ & $\begin{array}{l}0.2^{\mathrm{b}} \\
\pm 0.05 \\
\end{array}$ & $\begin{array}{l}0.21^{\mathrm{b}} \\
\pm 0.04\end{array}$ & $\begin{array}{l}0.23^{\mathrm{b}} \\
\pm 0.05\end{array}$ & $\begin{array}{l}0.23^{\mathrm{b}} \\
\pm 0.02 \\
\end{array}$ & $\begin{array}{l}0.22^{\mathrm{b}} \\
\pm 0.04\end{array}$ & $\begin{array}{l}0.35^{\mathrm{a}} \\
\pm 0.02\end{array}$ & $\begin{array}{l}0.23^{\mathrm{b}} \\
\pm 0.02\end{array}$ & $\begin{array}{l}0.23^{\mathrm{b}} \\
\pm 0.04\end{array}$ \\
\hline Specific growth rate & $\begin{array}{l}1.01^{\mathrm{b}} \\
\pm 0.1\end{array}$ & $\begin{array}{l}1.04^{\mathrm{b}} \\
\pm 0.1\end{array}$ & $\begin{array}{l}1.05^{\mathrm{b}} \\
\pm 0.1\end{array}$ & $\begin{array}{l}1.07^{b} \\
\pm 0.1\end{array}$ & $\begin{array}{l}1.06^{\mathrm{b}} \\
\pm 0.1\end{array}$ & $\begin{array}{l}1.13^{\mathrm{a}} \\
\pm 0.1\end{array}$ & $\begin{array}{l}1.08^{\mathrm{b}} \\
\pm 0.1\end{array}$ & $\begin{array}{l}1.07^{b} \\
\pm 0.1\end{array}$ \\
\hline $\begin{array}{l}\text { Condition factor } \\
\left(\mathrm{g} / \mathrm{cm}^{3}\right)\end{array}$ & $\begin{array}{l}2.04 \\
\pm 0.4 \\
\end{array}$ & $\begin{array}{l}2.04 \\
\pm 0.2 \\
\end{array}$ & $\begin{array}{l}2.05 \\
\pm 0.4 \\
\end{array}$ & $\begin{array}{l}2.05 \\
\pm 0.2 \\
\end{array}$ & $\begin{array}{l}2.04 \\
\pm 0.4\end{array}$ & $\begin{array}{l}2.08 \\
\pm 0.4 \\
\end{array}$ & $\begin{array}{l}2.05 \\
\pm 0.2\end{array}$ & $\begin{array}{l}2.06 \\
\pm 0.2 \\
\end{array}$ \\
\hline Survival rate $\%$ & 98 & 98 & 98 & 98 & 98 & 98 & 98 & 98 \\
\hline $\begin{array}{l}\text { Feed } \\
\text { (g/fish) }\end{array}{ }^{*}$ consumed & 35.0 & 38.0 & 35.0 & 35.0 & 38.0 & 36.0 & 35.0 & 33.0 \\
\hline $\begin{array}{l}\text { Feed conversion } \\
\text { ratio }\end{array}$ & $\begin{array}{l}1.41^{\mathrm{c}} \\
\pm 0.2^{2}\end{array}$ & $\begin{array}{l}1.47^{\mathrm{c}} \\
\pm 0.1\end{array}$ & $\begin{array}{l}1.28^{\mathrm{b}} \\
\pm 0.1\end{array}$ & $\begin{array}{l}1.26^{\mathrm{b}} \\
\pm 0.1\end{array}$ & $\begin{array}{l}1.44^{\mathrm{b}} \\
\pm 0.2^{2}\end{array}$ & $\begin{array}{l}1.13^{\mathrm{a}} \\
\pm 0.1\end{array}$ & $\begin{array}{l}1.25^{\mathrm{b}} \\
\pm 0.2\end{array}$ & $\begin{array}{l}1.17^{\mathrm{b}} \\
\pm 0.2\end{array}$ \\
\hline $\begin{array}{l}\text { Protein efficiency } \\
\text { ratio }\end{array}$ & $\begin{array}{l}1.76^{\mathrm{ab}} \\
\pm 0.1\end{array}$ & $\begin{array}{l}1.50^{\mathrm{c}} \\
\pm 0.2\end{array}$ & $\begin{array}{l}1.55^{\mathrm{c}} \\
\pm 0.1\end{array}$ & $\begin{array}{l}1.44^{\mathrm{c}} \\
\pm 0.1\end{array}$ & $\begin{array}{l}1.72^{\mathrm{ab}} \\
\pm 0.1\end{array}$ & $\begin{array}{l}1.96^{\mathrm{a}} \\
\pm 0.2\end{array}$ & $\begin{array}{l}1.60^{\mathrm{b}} \\
\pm 0.2\end{array}$ & $\begin{array}{l}1.56^{\mathrm{c}} \\
\pm 0.1\end{array}$ \\
\hline $\begin{array}{l}\text { Net protein } \\
\text { Utilization }(\%)\end{array}$ & $\begin{array}{l}33.84^{\mathrm{b}} \\
\pm 1.1\end{array}$ & $\begin{array}{l}28.56^{\mathrm{c}} \\
\pm 1.4\end{array}$ & $\begin{array}{l}29.36^{\mathrm{c}} \\
\pm 1.1\end{array}$ & $\begin{array}{l}28.11^{\mathrm{c}} \\
\pm 1.2\end{array}$ & $\begin{array}{l}32.75^{\mathrm{b}} \\
\pm 1.0\end{array}$ & $\begin{array}{l}37.50^{\mathrm{a}} \\
\pm 1.1\end{array}$ & $\begin{array}{l}36.26^{\mathrm{b}} \\
\pm 1.2\end{array}$ & $\begin{array}{l}29.80^{\mathrm{c}} \\
\pm 1.4\end{array}$ \\
\hline $\begin{array}{l}\text { Hepatosomatic } \\
\text { index }(\%)\end{array}$ & $\begin{array}{l}1.10 \\
\pm 0.1\end{array}$ & $\begin{array}{l}1.20 \\
\pm 0.2\end{array}$ & $\begin{array}{l}1.11 \\
\pm 0.1\end{array}$ & $\begin{array}{l}1.10 \\
\pm 0.1\end{array}$ & $\begin{array}{l}1.10 \\
\pm 0.2\end{array}$ & $\begin{array}{l}1.20 \\
\pm .0 .1\end{array}$ & $\begin{array}{l}1.10 \\
\pm .0 .2\end{array}$ & $\begin{array}{l}1.20 \\
\pm 0.1\end{array}$ \\
\hline
\end{tabular}

Means in the same row with different superscript letters are significantly different $(\mathrm{P}<0.05)$.

*Non-consumed portion of feed was collected, dried and deducted from total given ration. 
The results in Table (3) and Figs. ( $1 \& 2)$, indicated that the fish fed diet (45/12\%, protein/lipid) recorded the best value (low feed consumed with high gain), lower feed conversion ratio (FCR) compared to other experimental dietary groups. There were a significant differences $(\mathrm{P}<0.05)$ in protein efficiency ratio $(\mathrm{PER})$ and net protein utilization (NPU) among experimental groups with increasing dietary protein and lipid levels. However, the lower value was recorded in the fish fed diet with (55/8\%, protein/lipid). All dietary protein or lipid levels had no effect on condition factor (CF) and hepatosomatic index (HSI).

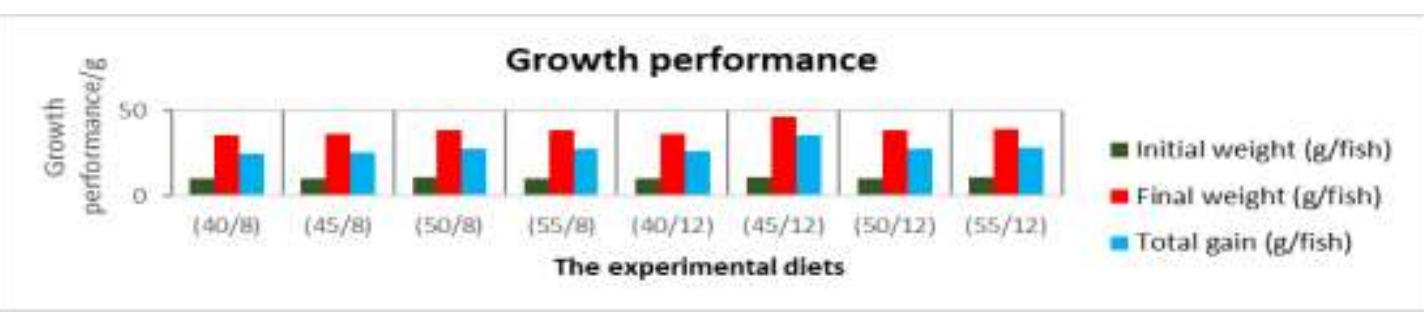

Fig. 1: Growth performance of Egyptian sole fed the experimential diet during 120 days.

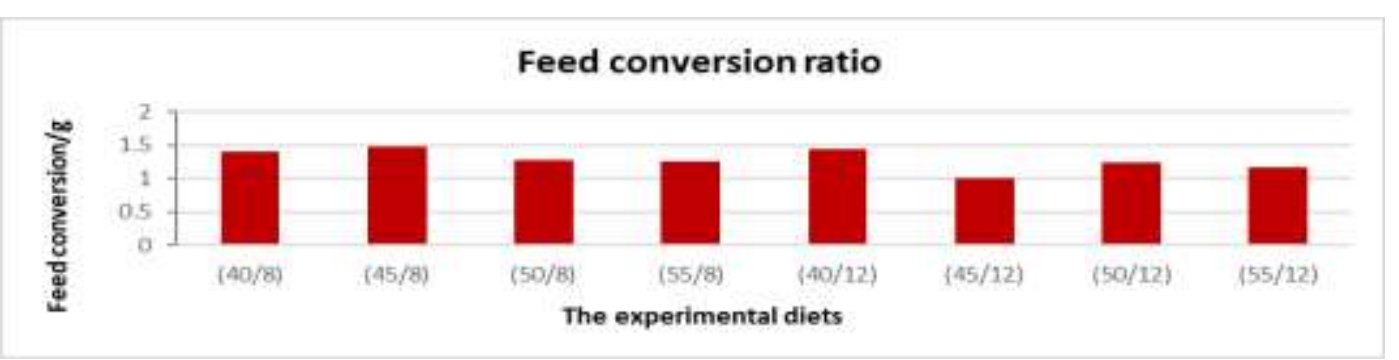

Fig. 2: Feed converison of Egyptian sole fed the experimential diets during 120 days.

Moreover, no significant different among experimental groups by dietary protein and lipid levels, there was a clear increase of the different digestibility coefficient ratios such as dry matter, crude protein, and crude lipid, and this was evident without significance differences among tested treatments according to ADCs of experimental diets as shown in Table (4). Furthermore, the ADCs of carbohydrate was decreased but not significantly affected by dietary protein and lipid levels.

Data in Table (5) illustrated that constitutes of the Sole juvenile whole body like dry matter, crude protein and ash were not affected by various dietary protein to lipid levels. On the contrary, fish treated with (50/12 and 55/12\% protein/lipid) showed a high significance difference $(\mathrm{P}<0.05)$ in the crude lipid content in comparison with other tested groups.

Table 4: Apparent digestibility coefficient (ADCs) of the experimental diets (Mean \pm S.E. $n=3$ ).

\begin{tabular}{|l|l|l|l|l|l|l|l|l|}
\hline \multirow{2}{*}{\multicolumn{1}{|c|}{ Parameters }} & \multicolumn{7}{|c|}{ Diets (protein/lipid \%) } \\
\cline { 2 - 9 } & $\mathbf{( 4 0 / 8 \% )}$ & $\mathbf{( 4 5 / 8 \% )}$ & $\mathbf{( 5 0 / 8 \% )}$ & $\mathbf{( 5 5 / 8 \% )}$ & $\mathbf{( 4 0 / 1 2 \% )}$ & $\mathbf{( 4 5 / 1 2 \% )}$ & $\mathbf{( 5 0 / 1 2 \% )}$ & $\mathbf{( 5 5 / 1 2 \% )}$ \\
\hline Dry mater & $92.6 \pm 1.2$ & $92.4 \pm 1.5$ & $91.8 \pm 1.6$ & $92.1 \pm 1.3$ & $92.5 \pm 1.4$ & $91.5 \pm 1.2$ & $91.2 \pm 01.5$ & $91.4 \pm 1.3$ \\
\hline Crude protein & $91.2 \pm 1.8$ & $91.4 \pm 1.4$ & $91.1 \pm 1.5$ & $91.5 \pm 1.4$ & $91.2 \pm 1.2$ & $91.1 \pm 1.5$ & $91.6 \pm 1.4$ & $91.4 \pm 1.5$ \\
\hline Crude lipid & $93.5 \pm 1.4$ & $93.2 \pm 1.6$ & $93.4 \pm 1.2$ & $93.6 \pm 1.4$ & $93.3 \pm 1.5$ & $93.1 \pm 1.5$ & $93.6 \pm 1.2$ & $93.2 \pm 1.4$ \\
\hline Carbohydrate & $55.2 \pm 1.2$ & $55.4 \pm 1.4$ & $55.2 \pm 1.2$ & $55.3 \pm 1.4$ & $55.2 \pm 1.5$ & $55.5 \pm 1.2$ & $55.8 \pm 1.4$ & $55.2 \pm 1.2$ \\
\hline
\end{tabular}

Means in the same row with different superscript letters are significantly different $(\mathrm{P}<0.05)$.

Table 5: Proximate analysis of Egyptian sole fed on the experimental diets, Mean \pm S.E. (\%w/w basis).

\begin{tabular}{|l|l|l|l|l|l|l|l|l|}
\hline \multirow{2}{*}{ Parameters } & \multicolumn{7}{|c|}{ Diets (protein/lipid \%) } \\
\cline { 2 - 9 } & $\mathbf{( 4 0 / 8 \% )}$ & $\mathbf{( 4 5 / 8 \% )}$ & $\mathbf{( 5 0 / 8 \% )}$ & $\mathbf{( 5 5 / 8 \% )}$ & $\mathbf{( 4 0 / 1 2 \% )}$ & $\mathbf{( 4 5 / 1 2 \% )}$ & $\mathbf{( 5 0 / 1 2 \% )}$ & $\mathbf{( 5 5 / 1 2 \% )}$ \\
\hline Dry mater & $28.1 \pm 1.2$ & $28.2 \pm 1.4$ & $28.0 \pm 1.6$ & $28.2 \pm 1.3$ & $28.8 \pm 1.4$ & $28.5 \pm 1.2$ & $28.7 \pm 01.5$ & $28.9 \pm 1.4$ \\
\hline Crude protein & $19.2 \pm 1.4$ & $19.4 \pm 1.6$ & $19.1 \pm 1.2$ & $19.5 \pm 1.1$ & $19.1 \pm 1.4$ & $19.2 \pm 1.2$ & $19.0 \pm 1.4$ & $19.2 \pm 1.2$ \\
\hline Crude lipid & $5.1^{\mathrm{b}} \pm 1.4$ & $5.2^{\mathrm{b}} \pm 1.6$ & $5.1^{\mathrm{b}} \pm 1.2$ & $5.2^{\mathrm{b}} \pm 1.4$ & $6.3^{\mathrm{a}} \pm 1.5$ & $6.1^{\mathrm{a}} \pm 1.5$ & $6.5^{\mathrm{a}} \pm 1.2$ & $6.6^{\mathrm{a}} \pm 1.4$ \\
\hline Ash & $3.8 \pm 1.1$ & $3.6 \pm 1.4$ & $3.8 \pm 1.2$ & $3.5 \pm 1.4$ & $3.4 \pm 1.5$ & $3.2 \pm 1.2$ & $3.2 \pm 1.4$ & $3.1 \pm 1.2$ \\
\hline
\end{tabular}


Means in the same row with different superscript letters are significantly different $(\mathrm{P}<0.05)$. Initial body composition (\% wet weight) was dry matter $27.6 \%$, crude protein $19.4 \%$, crude fat $4.0 \%$, and ash $4.2 \%$.

As shown in Table $(6)$, there was a significant $(\mathrm{P}<0.05)$ higher lipid content, hepatic glycogen concentrations, and hepatic enzymes related of Juvenile sole fed the different protein/lipid diets. Dietary protein to lipid concentrations had a significant $(\mathrm{P}<0.05)$ effect on liver lipid content. The results revealed that hepatic glycogen, liver lipid; AST and ALT concentrations were significantly $(\mathrm{P}<0.05)$ increased with the increasing dietary lipid from 8 to12 $\%$. Further, the results showed that the diets containing 12\% lipid, had significant highest $(\mathrm{P}<0.05)$ AST and ALT than the rest of experimental groups.

Table 6: Hepatic glycogen, liver lipid, AST and ALT of Egyptian sole fed on the experimental diets, Mean \pm S.E. $n=3$ (\%w/w basis).

\begin{tabular}{|c|c|c|c|c|c|c|c|c|}
\hline \multirow{2}{*}{ Parameters } & \multicolumn{8}{|c|}{ Diets (protein/lipid \%) } \\
\hline & $(40 / 8 \%)$ & $(45 / 8 \%)$ & $(50 / 8 \%)$ & $(55 / 8 \%)$ & $(40 / 12 \%)$ & $(45 / 12 \%)$ & $(50 / 12 \%)$ & $(55 / 12 \%)$ \\
\hline $\begin{array}{l}\text { Hepatic } \\
\text { glycogen } \\
(\mathrm{mg} / \mathrm{g})\end{array}$ & $39.2^{\mathrm{c}} \pm 1.4$ & $39.7^{\mathrm{c}} \pm 1.8$ & $40.4^{\mathrm{c}} \pm 1.6$ & $40.2^{\mathrm{c}} \pm 1.4$ & $45.2^{\mathrm{b}} \pm 1.2$ & $46.1^{\mathrm{b}} \pm 1.8$ & $48.4^{\mathrm{a}} \pm 1.5$ & $48.8^{\mathrm{a}} \pm 1.4$ \\
\hline $\begin{array}{l}\text { Lipid of } \\
\text { liver }(\mathrm{mg} / \mathrm{g})\end{array}$ & $15.4^{\mathrm{c}} \pm 1.2$ & $15.2^{\mathrm{c}} \pm 1.5$ & $15.5^{\mathrm{c}} \pm 1.4$ & $15.1^{\mathrm{c}} \pm 1.1$ & $20.2^{\mathrm{b}} \pm 1.6$ & $22.4^{\mathrm{b}} \pm 1.4$ & $24.5^{\mathrm{a}} \pm 1.5$ & $25.0^{\mathrm{a}} \pm 1.2$ \\
\hline $\begin{array}{l}\text { AST (U/mg } \\
\text { protein) }\end{array}$ & $6.6^{\mathrm{c}} \pm 1.2$ & $6.7^{\mathrm{c}} \pm 1.4$ & $6.9^{c} \pm 1.0$ & $6.4^{\mathrm{c}} \pm 1.1$ & $14.4^{\mathrm{b}} \pm 1.5$ & $14.8^{\mathrm{b}} \pm 1.2$ & $17.2^{\mathrm{a}} \pm 1.1$ & $17.5^{\mathrm{a}} \pm 1.6$ \\
\hline $\begin{array}{l}\text { ALT (U/mg } \\
\text { protein) }\end{array}$ & $7.9^{\mathrm{c}} \pm 1.4$ & $7.8^{\mathrm{c}} \pm 1.2$ & $7.6^{\mathrm{c}} \pm 1.5$ & $8.1^{\mathrm{c}} \pm 1.2$ & $16.2^{\mathrm{b}} \pm 1.4$ & $17.1^{\mathrm{b}} \pm 1.1$ & $20.2^{\mathrm{a}} \pm 1.2$ & $20.8^{\mathrm{a}} \pm 1.8$ \\
\hline
\end{tabular}

Means in the same row with different superscript letters are significantly different $(\mathrm{P}<0.05)$.

\section{DISCUSSION}

Egyptian sole, Solea aegyptiaca juveniles fed the diets containing (45/12\%, protein/lipid) showed the highest growth performance values compared with the other feeding groups suggesting a protein sparing by dietary lipid. However, the protein level at 50 and $55 \%$ with $12 \%$ lipid level, showed a decrease in the performance of Sole fish. The dietary non-protein energy is the main reason for the growth resulting from protein and lipid levels, these results were similar to the results of (McGoogan and Gatlin, 1999; Kim and Lee, 2005; Alam et al., 2008).

Many authors also reported that there is a protein level beyond which further growth is not supported and may even decrease it where energy was speculated to be insufficient (McGoogan and Gatlin, 1999). This might be explained a proportion of protein will be deaminated, and the carbon skeleton used as an energy source at the high dietary protein level. The excreted ammonia nitrogen leads to deterioration of water quality, so elevated levels of a dietary protein that do not enhance production characteristics should be avoided (Azevedo et al., 2002, 2004; El-Sayed and Kawanna, 2008).

The current data were identical with those of (Guerreiro et al., 2012; Borges et $a l ., 2009)$ in the Senegalese sole, they recoded that the best performance achieved with diets including either $550 \mathrm{~g} \mathrm{~kg}^{-1}$ protein or $450 \mathrm{~g} \mathrm{~kg}^{-1}$ protein, depending on dietary lipid content. In the opposite of these studies Dias et al. (2004) who observed no significant effects on growth performance or protein deposition by increasing dietary lipids from $110 \mathrm{~g} \mathrm{~kg}^{-1}$ to $210 \mathrm{~g} \mathrm{~kg}^{-1}$ in $510 \mathrm{~g} \mathrm{~kg}^{-1}$ protein diets. A protein 
sparing by dietary lipids was also reported in some studies with flatfish (Cho et al., 2005) but not in others (Lee et al., 2000; Martins et al., 2007).

The apparent discrepancy between studies may be related to the dietary protein levels used in many various experiments. The protein requirements may affect by other factors, comprised, fish species, life stage, dietary protein sources, non-protein energy sources and levels, amino acid composition and digestibility of the protein source, experimental design, and culture environmental conditions.

The highest feed utilization from FCR, PER, and NPU were obtained in diet $(45 / 12 \%)$ protein to lipid levels, these results were in agreement with the values recorded in the same species (Solea aegyptiaca) by (Yones and Abdel-Hakim, 2011; Yones and Metwally, 2014), and Senegalese sole (Guerreiro et al., 2012).

Fish, like other animals, control in their feed intake to meet their energy requirements (Kaushik and Medale, 1994), but excessive energy in the diets is undesirable because it may reduce feed intake, these results in a depression in growth and feed efficiency because a lack of necessary nutrients such as protein for normal growth (Mohanta et al., 2007). In the current study, both dietary protein and lipid levels affected the feed intake, whereas it decreased with treated diet (55/12\%, protein/lipid) than that of other dietary diets. These results are similar to other studies (McGoogan and Gatlin 1999; Kim and Lee 2005, 2017; Mohanta et al., 2007).

Apparent digestibility of the tested diets was not affected by different dietary protein and lipid levels. Similar results were reported in juveniles of Senegalese sole fed 540-560 g protein $/ \mathrm{kg}$ diet (Cabral et al., 2011; Borges et al., 2013). Moreover, other species such as rainbow trout for dry matter, crude lipid, carbohydrate, and crude protein digestibility was significantly different (Gai et al., 2016). However, Sales-Leiton et al. (2018) displayed low digestibility values in Senegalese sole. The controversial digestibility values might influenced by the different origin, processing conditions of raw material and the genetic origin of the fish.

Sole, Senegalese sole is considered a lean fish with lipid contents, 6\% (Dais et al., 2004; Rema et al., 2008), these findings agree with the values reported in the present study. Also, whole-body lipid significantly $(\mathrm{P}<0.05)$ increased with increasing dietary lipid level from 8 to $12 \%$, which in accordance with the results in this species (Dias et al., 2004; Borges et al., 2009, 2013; Cabral et al., 2013), and in other flatfish species (Van Ham et al., 2003; Fang et al., 2010; Lv et al., 2015).

In the present study, HSI values ranged from 1.0 to $1.2 \%$, within the ranges were found in the same species (Yones and Abdel-Hakim, 2011; Yones and Metwally, 2014) and in other flatfish species (Hemre et al., 2003; Peres and OlivaTeles 2005; Martins et al., 2007). HSI was not affected by dietary lipid levels, indicating that the liver was not the main site for body fat storage. However, Dais et al. (2004) and Borges et al. (2009) observed that the HSI was higher in Senegalese sole fed with high-fat diet.

Hepatic glycogen concentrations, lipids, AST, and ALT in fish liver were also significantly affected by dietary lipid levels. AST and ALT in fish liver were significantly $(\mathrm{P}<0.05)$ increased with increasing dietary lipid level. The activities of AST and ALT are useful to evaluate the feeding status in some fish (Moyano et al., 1991; Melo et al., 2006).

High protein level or protein/energy ratio usually causes an increase of liver AST and ALT (Meton et al., 1999; Liu et al., 2013). In this study, the increase of hepatic ALT and AST suggests that 12\% lipid level in diets of Sole may affect protein metabolism. Rueda-Jasso et al. (2004) also reported that the high dietary lipid affected the oxidative status of Senegalese sole and inhibited the growth rate of fish. 
Therefore, more studies are needed to elucidate the optimum dietary lipid level and the metabolism of the Sole in the future.

\section{CONCLUSION}

In conclusion, the results of this investigation confirmed a maximal dietary inclusion level of $45 \%$ protein and $12 \%$ lipid was recommended for both optimal growth and nutrient utilization for Sole juveniles, Solea aegyptiaca. In addition, a protein-sparing effect by dietary lipid was recorded.

Future studies are required to better understanding on both nutrient digestibility and metabolic changes induced by dietary protein/lipid ratio should allow adjustment the diet composition to the metabolic efficiency of Egyptian sole (Solea aegyptiaca) juveniles.

\section{REFERENCES}

Ai, Q.H.; Mai, K.S.; Li, H.; Zhang, C.; Zhang, L.; Duan, Q.; Tan, B.; Xu, W.; Ma, H.; Zhang, W. and Liufu, Z. (2004). Effects of dietary protein to energy ratios on growth and body composition of juvenile Japanese seabass, Lateolabrax japonicas. Aquaculture, 230: 507-516.

Alam, M.S.; Watanabe, W.O. and Carroll, P.M. (2008). Dietary protein requirements of juvenile Black seabass (Centropristis striata). Journal of world Aquaculture Society, 39: 656-663.

Andersen, N. and Alsted, N.S. (1993). Growth and body composition of turbot (Scophthalmus maximus L.) in relation to different lipid/protein ratios in the diet. In: Fish Nutrition in Practice. LesColloques, 61, INRA, Vol. 61 (Kaushik, S.J. \& Luquet, P.eds), pp. 479-491. INRA, Paris, France.

AOAC (2006). Official Methods of Analysis of AOAC International, 18th ed., chapter 32, pp.38-39. Gaithersburg, MD: AOAC International.

APHA (1992). Standard methods for the examination of water and waste water. American Public Health Association, Washington, DC, 1134 pp.

Assem, S.; El-Dahhar, A.; Heba, S.; Salama, M. and Mourad, M. (2012). Induced Spawning, embryonic and larval developmental stages of Solea vulgaris in the Mediterranean water. Journal of Arabian aquaculture Society, 7: 51-74.

Azevedo, P.A.; Bureau, D.P.; Leeson, S. and Cho, C.Y. (2002). Growth and efficiency of feed usage by Atlantic salmon (Salmo salar) fed diets with different dietary protein: energy ratios at two feeding levels. Fish. Sci., 68: 878-888.

Azevedo, P.A.; Leeson, S.; Cho, C.Y. and Bureau, D. P. (2004). Growth, nitrogen and energy utilization of juveniles from four salmonid species: Diet, species and size effects. Aquaculture, 234: 393-414.

Berge, G.M. and Storebakken, T. (1991). Effect of dietary-fat level on weight gain, digestibility and fillet composition of Atlantic halibut. Aquaculture, 99: 331338.

Borges, P.; Oliveira, B.; Casal, S.; Dias, J.; Conceic sao, L. and Valente, L.M.P. (2009). Dietary lipid level affects growth performance and nutrient utilization of Senegalese sole (Solea senegalensis) juveniles.Br. J. Nutr., 102: 1007-1014.

Borges, P.; Medale, F.; Dias, J. and Valente, L.M.P. (2013). Protein utilization and intermediary metabolism of Senegalese sole (Solea senegalensis) as a function of protein: Lipid ratio. British Journal of Nutrition, 109: 1373-1381. 
Cabral, E.M.; Bacelar, M.; Batsta, S.; Castro-Cunha, M.; Ozório, R.O.A., and Valente, L.M.P. (2011). Replacement of fishmeal by increasing levels of plant protein blends in diets for Senegalese sole (Solea senegalensis) juveniles. Aquaculture, Vol, 322-323: 74-81.

Cabral, E.M.; Fernandes, T.J.R.; Campos, S.D.; Castro-Cunha, M.; Oliveira, M.B.P.P.; Cunha, L.M., and Valente, L.M.P. (2013). Replacement of fishmeal by plant protein sources up to $75 \%$ induces good growth performance without affecting flesh quality in growing Senegalese sole. Aquaculture, Vol, 380-383: $130-138$.

Canãvate, J.P.; Zerolo, R. and Ferna'ndez-Dı'az, C. (2006). Feeding and development of Senegal sole (Solea senegalensis) larvae reared in different photoperiods. Aquaculture, 258(1-4): 368-377.

Cho, S.H.; Lee, S.M.; Lee, S.M. and Lee, J.H. (2005). Effect of dietary protein and lipid levels on growth and body composition of juvenile turbot (Scophthalmus maximus L.) reared under optimum salinity and temperature conditions. Aquacult. Nutr., 11: 235-240.

Conceic ,a ${ }^{\sim}$, L.E.C.; Ribeiro, L.; Engrola, S.; Aragao, C.; Morais, S.; Lacuisse, M.; Soares, F. and Dinis, M.T. (2007). Nutritional physiology during development of Senegalese sole (Solea senegalensis). Aquaculture, 268: 64-81.

Deng, D.F.Z.Y.; Ju, W.; Dominy, R.; Murashige R. and Wilson, R.P. (2011). Optimal dietary protein levels for juvenile Pacific threadfin (Polydactylus sexfilis) fed diets with two levels of lipid. Aquaculture, 316: 25-30.

Dias, J.; Rueda-Jasso, R.; Panserat, S.; da Conceic a o, L.E.C.; Gomes, E.F. and Dinis, M.T. (2004). Effect of dietary carbohydrate to-lipid ratios on growth, lipid deposition and metabolic hepatic enzymes in juvenile Senegalese sole (Solea senegalensis). Aquacult. Res., 35: 1122-1130.

Dinis, M.T.; Ribeiro, L.; Soares, F. and Sarasquete, C. (1999). A review on the cultivation potential of Solea senegalensis in Spain and in Portugal. Aquaculture, 176: 27-38.

Dinis, M.T.; Ribeiro, L.; Conceic ão, L.E.C. and Aragão, C. (2000). Larvae digestion and new weaning experiments in Solea senegalensis. In: Recent Advances in Mediterranean Aquaculture Finfish Species Diversification, Vol. 47 (Ciheam-Iamz), pp.193-204.Ciheam, Zaragoza, Spain.

Duncan, D. B. (1955). Multiple ranges and multiple F. test. Biometric 11:1-42.

El-Sayed, A-F. M. and Kawanna, M. (2008). Effects of dietary protein and energy levels on spawning performance of Nile tilapia (Oreochromis niloticus) broodstock in a recycling system. Aquaculture, 280: 179-184.

Fang, J.; Tian, X. and Dong, S. (2010). The influence of water temperature and ration on the growth, body composition and energy budget of tongue sole (Cynoglossus semilaevis).Aquaculture, 299: 106-114.

Folch, J.; Lees, M. and Sloane Stanley, G.H. (1957). A simple method for the isolation and purification of total lipids from animal tissues. J. Biol. Chem, 226: 497-509.

Fonds, M. (1976).The influence of temperature and salinity on growth of young sole (Solea solea L.) Eur. Symp.Mar.Biol., 1: 109-125.

Gabr, H. R.; Ahmed, A. and Haraz, M. (2003). Aquaculture potential of the flatfish (Solea vulgaris) in Egypt. Journal of Egyptian Academic Society for environmental development. Aquaculture Bu (2): 157-168.

Gai, F.; Peiretti, P.G.; Brugiapaglia, A. and Gasco, L. (2016). Effects of dietary protein source and feeding regime on growth performance, nutrient 
digestibility, fatty acids, and quality characteristics of rainbow trout, Oncorhynchus mykiss, fillets. Journal of world Aquaculture Society, 47: 496507.

Guerreiro, I.; Peres, H.; Castro-Cunha, M. and Oliva-Teles, A. (2012). Effect of temperature and dietary protein/lipid ratio on growth performance and nutrient utilization of juvenile Senegalese sole (Solea senegalensis). Aquacult. Nutr. 18: 98-106.

Helland, S.J. and Grisdale-Helland, B. (1998). Growth, feed utilization and body composition of juvenile Atlantic halibut (Hippoglossus hippoglossus) fed diets differing in the ratio between the macronutrients. Aquaculture, 166: 49-56.

Hemre, G.-I.; Karlsen, Ø; Mangor-Jensen, A. and Rosenlund, G. (2003). Digestibility of dry mater, protein, starch and lipid by cod, Gadus morhua: Comparison of sampling methods. Aquaculture, 25: 225-232.

Imsland, A.K.; Foss, A.; Conceic,ão, L.E.C.; Dinis, M.T.; Delbare, D.; Schram, E.; Kamstra, A.; Rema, P. and White, P. (2003). A review of the culture potential of Solea solea and S. senegalensis. Rev. Fish Biol. Fish, 13: 379-407.

Jobling, M. (1994). Fish bioenergetics, Series, 13 published by Chapman \& Hall-2-6 Boundary, R, London SBI 8HN, 300 pp.

Kim, L.O. and Lee, S.M. (2005). Effects of the dietary protein and lipid levels on growth and body composition of bagrid catfish, Pseudobagrus fulvidraco. Aquaculture, 24: 323-329.

Kim, K.W.; Kim, K.D. and Ham, H.S. (2017). Optimum dietary protein level and protein to energy ratio for growth of juvenile parrot fish (Oplegnathus fasciatus). Journal of world Aquaculture Society, Vol, 48: 407-477.

Kariman, A.S. (2009). Some observation on fisheries biology of Tilapia zillii (Gervais, 1884) and Solea vulgaris (Quensel, 1806 in lake Qarun, Egypt. World Journal of Fish and Mar. Sci., 1: 20-28.

Kaushik, S.J. and Medale, F. (1994). Energy requirements, utilization and dietary supply to salmonids. Aquaculture, 124: 81-97.

Lee, S.M.; Cho, S.H. and Kim, K.D. (2000). Effects of dietary protein and energy levels on growth and body composition of juvenile flounder Paralichthys olivaceus. J. World Aquac. Soc., 31: 306-315.

Liu, X.; Kangsen, M.; Qinghui, A.; Xiaojie, W.; Zhiguo, L. and Yamjiao, Z. (2013). Effects of protein and lipid levels in practical diets on growth and body composition of tong sole (Cynoglossus semilaevis) Gunther. Journal of World Aquaculture Society Vol. 44: 96-104.

Lozano, N.B.S.; Vidal, A.T.; Martinez-Llorens, S.; Merida, S.N.; Blanco, J.E.; Lobez, A.M.; Torres, M.P. and Cerda, M.J. (2007). Growth and economic profit of gilthead seabream (Sparus aurata L.) fed on sunflower meal. Aquaculture, 272: 528-534.

Lv, Y.; Chang, Q.; Chen, S.; Yu, C. and Wang, Q. (2015). Effect of Dietary Protein and Lipid Levels on Growth and Body Composition of Spotted Halibut, Verasper variegatus. Journal of World Aquaculture Society, 46: 311-318.

Martins, D.A.; Valente, L.M.P. and Lall, S.P. (2007). Effects of dietary lipid level on growth and lipid utilization by juvenile Atlantic halibut (Hippoglossus hippoglossus, L.). Aquaculture, 263: 150-158.

McGoogan, B.B. and Gatlin, D.M. (1999). Dietary manipulations affecting growth and nitrogenous waste production of red drum, Sciaenops ocellatus. Effects of dietary protein and energy levels. Aquaculture 178: 333-48. 
Melo, J.F.B.; Lundstedt, L.M.; Meton, I.; Baanante, I.V. and Moraes, G. (2006). Effects of dietary levels of protein on nitrogenous metabolism of Rhamdia quelen (Teleostei Pimelodidae). Comparative Biochemistry and Physiology. Part A, 145: 181-187.

Meton, I.; Mediavilla, D.; Caseras, A.; Canto, E.; Fernandez, F. and Baanante, I.V. (1999). Effect of diet composition and ration size on key enzyme activities of glycolysis-luconeogenesis, the pentose phosphate pathway and amino acid metabolism in liver of gilthead seabream (Sparus aurata). British Journal of Nutrition 82: 223-232.

Mohanta, K.N.; Mohanty, N.S.; Jena, J.K. and Sahu, N.P. (2007). Optimal dietary lipid level of silver barb, Puntius gonionotus fingerlings in relation to growth, nutrient retention and digestibility, muscle nucleic acid content and digestive enzyme activity. Aquaculture Nutrition 14: 350-359.

Montero, D.; Grasso, V.; Izquierdo, M.S.; Ganga, R.; Real, F.; Tort, L.; Caballero, M. J. and Acosta, F. (2008). Total substitution of fish oil by vegetable oils in gilthead seabream (Sparus aurata) diets: effects on hepatic Mx expression and some immune parameters. Fish and Shellfish Immunology 24: 147-155.

Moyano, F.J.; Cardenete, G. and De La Higuera, M. (1991). Nutritive and metabolic utilization of proteins with high glutamic acid content by the rainbow trout (Oncorhynchus mykiss). Comparative Biochemistry and Physiology. Part A, 100: 759-762.

Nasopoulou, C. and Zabetakis, I. (2012). Benefits of fish oil replacement by plant originated oils in compounded fish feeds. A review. LWT - Food Science and Technology 47: 217-224.

Ng, W.K.; Abdullah, N. and De Silva, S.S. (2008). The dietary protein requirement of the Malaysian mahseer, Tor tambroides (Bleeker), and the lack of protein-sparing action by dietary lipid. Aquaculture, 284: 201-206.

Ozorio, R.O.A.; Valente, L.M.P.; Pousao-Ferreira, P. and Oliva-Teles, A. (2006). Growth performance and body composition of white seabream (Diplodus sargus) juveniles fed diets with different protein and lipid levels. Aquaculture Research, 37: 255-263.

Pan, L.Q. and Wang, K.X. (1997). The experimental studies on activities of digestive enzyme in the larvae Penaeus chinensis. Journal of Fisheries of China, 21: 2631.

Peres, M.H. and Oliva-Teles, A. (1999). Influence of temperature on protein utilization in juvenile European seabass (Dicentrarchus labrax). Aquaculture, 170: 337-348.

Peres, H. and Oliva-Teles, A. (2005). The effect of dietary protein replacement by crystalline amino acid on growth and nitrogen utilization of turbot, Scophthalmus maximus juveniles. Aquaculture, 250: 755-764.

Regost, C.; Arzel, J.; Cardinal, M.; Robin, J.; Laroche, M. and Kaushik, S.J. (2001). Dietary lipid level, hepatic lipogenesis and flesh quality in turbot (Psetta maxima). Aquaculture, 193: 291-309.

Rema, P.; Conceic,ão, L.E.C.; Evers, F.; Castro-Cunha, M.; Dinis, M.T. and Dias, J. (2008). Optimal dietary protein levels in juvenile Senegalese sole (Solea senegalensis). Aquacult. Nutr. 14: 263-269.

Rueda-Jasso, R.; Conceição, L.E.C.; Dias, J.; DeCoen, W.; Gomes, E.; Rees, J.F. and Sorgeloos, P. (2004). Effect of dietary non-protein energy levels on condition and oxidative status of Senegalese sole (Solea senegalensis) juveniles. Aquaculture, 231: 417-433. 
Salas-Leiton, E.; Conde-Sieira, M.; Pelusio1, N.; Marques1, A.; Maia, M.R.G.; Soengas, J.L. and Valente, L.M.P. (2018). Dietary protein/ carbohydrate ratio in low-lipid diets for Senegalese sole (Solea senegalensis, Kaup1858) juveniles. Influence on growth performance, nutrient utilization and flesh quality. Aquacult. Nutr. 24: 131-142.

Sargent, J.; McEvoy, L. and Estevez, A. (1999). Lipid nutrition of marine fish during early development: current status and future directions. Aquaculture, 179: 217229.

SPSS Inc. (Released 2009). SPSS Statistics for Windows, Version 18.0. Chicago: SPSS Inc, USA.

Thoman, E.S.; Davis, D.A. and Arnold, C.R. (1999). Evaluation of grow out diets with varying protein and energy levels for red drum (Sciaenops ocellatus). Aquaculture, 176: 343-353.

VanHam, E.H.; Berntssen, M.H.G.; Imsland, A.K.; Parpoura, A.C.; Bonga, S.E.W. and Stefansson, S.O. (2003). The influence of temperature and ration on growth, feed conversion, body composition and nutrient retention of juvenile turbot (Scophthalmus maximus). Aquaculture, 217: 547-558.

Xu, H.; Zhang, Y.; Wang, J.; Zuo, R.; Mai, K. and Ai, Q. (2015). Replacement of Fish Oil with Linseed Oil or Soybean Oil in Feeds for Japanese Seabass, Lateolabrax japonicus: Effects on Growth Performance, Immune Response, and Tissue Fatty Acid Composition. Journal world aquaculture society, 46: 349-362.

Yamamoto, T.; Sugita, T. and Furuita, H. (2005). Essential amino acid supplementation to fish meal-based diets with low protein to energy ratios improves the protein utilization in juvenile rainbow trout, Oncorhynchus mykiss. Aquaculture, 246: 379-391.

Yones, A.M. and Abdel-Hakim, N.F. (2011). Dietary protein requirements for Juvenile sole, Solea aegyptiaca (Chabanaud, 1927). Egypt J. Aquat. Biol. \&Fish, 15(1): 71-87.

Yones, A.M. and Metwalli, A.A. (2014). Incorporation of silverside meal to enhance diet palatability, growth performance and body composition of fingerlings sole, Solea aegyptiaca (Chabanaud, 1927) Egypt J. Aquat. Biol. \& Fish, 15(4): 7992.

Williams, K.C.; Barlow, C.G.; Rodgers, L.; Hockings, I.; Agcopra, C. and Ruscoe, I. (2003). Asian seabass, Lates calcarifer perform well when fed pelleted diets high in protein and lipid. Aquaculture, 225: 191-206.

Zaki, M. I. and Hamza, A. K. (1988). Artificial fertilization and developmental stages of Solea solea. J. Folia morphological. Vol. (36): 229-242.

Zaki, M.L. and Hamza, A.K. (1986). Reproductive biology and induced spawning of Solea solea in Egypt Bull. Inst. Ocean. \& Fish. A.R.E., 12: 115-125. 


\section{ARABIC SUMMARY}

\section{تأثير التغذية بمستويات عدة من البروتين والدهن على القياسات الغذائية ووظائف الكبد لأصبعيات أسماك}

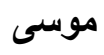

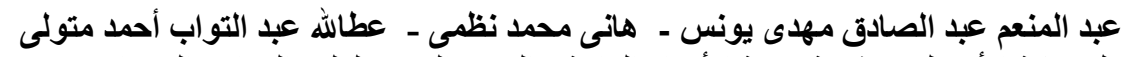

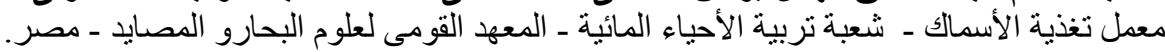

أجريت هذة التجربة لتقييم تأثثير إستخدام مستويات مختلفة من البروتين و الدهن لتحديد المستوى الأمثل

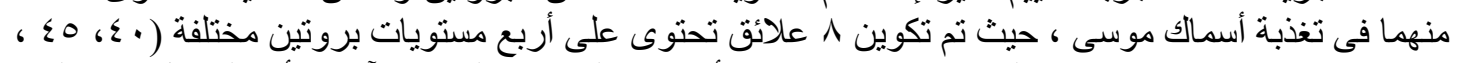

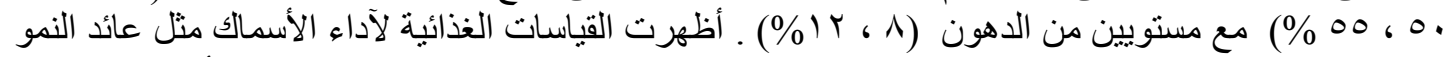

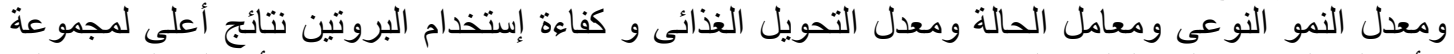

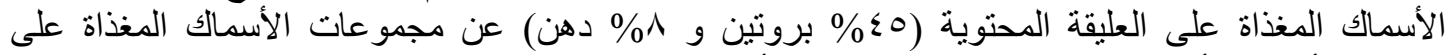

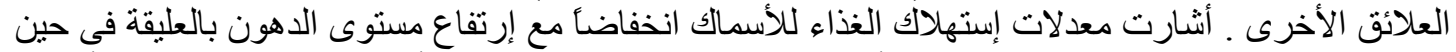

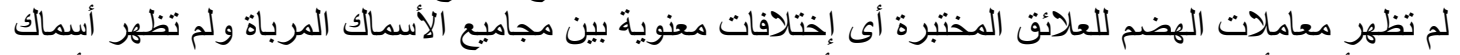

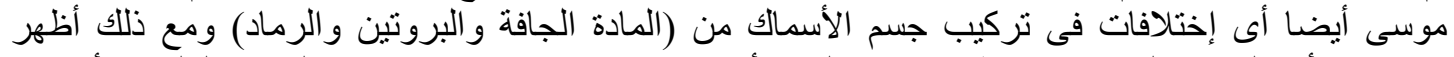

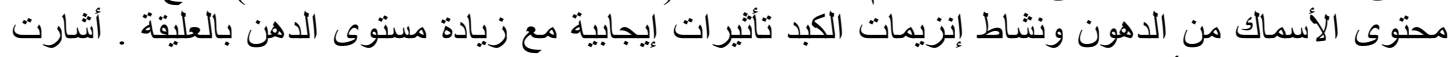

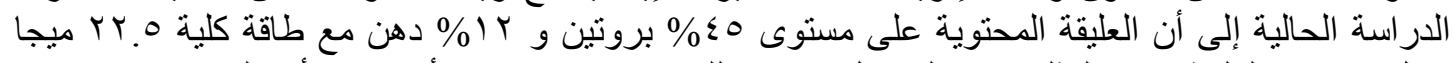

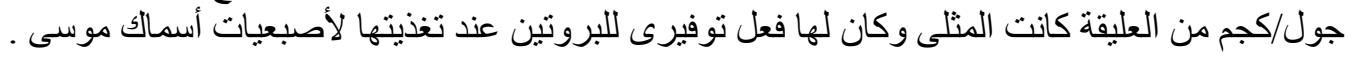

